\title{
Exploring the sulfide tolerance of ectosymbiotic Niphargus amphipods from the Frasassi caves, central Italy
}

\author{
Jan Bauermeister, Karoline Assig, and Sharmishtha Dattagupta* \\ Courant Research Center Geobiology, Georg-August University of Göttingen, Goldschmidtstraße 3, 37077 Göttingen, Germany
}

\begin{abstract}
Two species of the crustacean amphipod genus Niphargus inhabit the sulfidic groundwaters of the Frasassi caves in central Italy, and both harbor filamentous, sulfide-oxidizing Thiothrix ectosymbionts. As sulfide is toxic to most aerobic organisms, it appeared possible that the ectosymbionts could help their Niphargus hosts with detoxification processes. In this study, mortality due to sulfide was compared between Niphargus individuals with ectosymbionts and individuals whose ectosymbionts had been killed by antibiotic treatment. Both Frasassidwelling Niphargus species revealed exceptionally high tolerances to sulfide compared to other amphipod species studied so far. Niphargus individuals without viable ectosymbionts tolerated sulfide levels exceeding those occurring in Frasassi cave waters. Thus, the amphipods may employ Thiothrix-independent mechanisms for sulfide resistance.
\end{abstract}

Keywords: $\quad$ ectosymbionts; Frasassi caves; Niphargus; sulfide tolerance; Thiothrix

Received 8 April 2013; Revised 7 May 2013; Accepted 9 May 2013

Citation: Bauermeister J., Assig K. and Dattagupta S., 2013. Exploring the sulfide tolerance of ectosymbiotic Niphargus amphipods from the Frasassi caves, central Italy. International Journal of Speleology, 42 (2), 141-145. Tampa, FL (USA) ISSN 0392-6672 http://dx.doi.org/10.5038/1827-806X.42.2.6

\section{INTRODUCTION}

The Frasassi caves are located in the Apennine Mountains of the Marche region in central Italy and are actively forming by sulfuric acid-driven limestone dissolution (Galdenzi, 1990). Sulfide in the cave waters fuels primary productivity by chemoautotrophic microbes, which supports the food web of the ecosystem (Sarbu et al., 2000). Sulfide is toxic to most invertebrates, as it binds to cytochrome $c$ oxidase and inhibits mitochondrial electron transport (Nicholls, 1975). Nevertheless, crustacean amphipods of the species Niphargus ictus and Niphargus frasassianus live in the sulfidic Frasassi cave waters (Flot et al., 2010). Both species harbor filamentous, sulfideoxidizing Thiothrix ectosymbionts (Dattagupta et al., 2009; Bauermeister et al., 2012).

A variety of invertebrates living in sulfide-rich marine habitats employ effective strategies, partially involving microbial symbionts, to avoid sulfide poisoning (Cavanaugh et al., 2006; Dubilier et al., 2008). Deep-sea tubeworms and shallow-water clams host intracellular endosymbionts that can oxidize hydrogen sulfide to nontoxic sulfur compounds (Anderson et al., 1987; Wilmot $\&$ Vetter, 1990). A sulfide-detoxifying role has further been proposed for ectosymbiotic bacteria covering the cuticles of stilbonematid nematodes (Hentschel et al., 1999) and for those on the gill surfaces of hydrothermal- vent shrimp (Tokuda et al., 2008). On the other hand, it has been argued that the diffusion rate of sulfide into the bodies of oligochaete worms and other invertebrates far exceeds the rate at which it can be oxidized by their ectosymbionts (Dubilier et al., 1995; Ruehland \& Dubilier, 2010). Thus, whether or not sulfur-oxidizing ectosymbionts can assist their hosts in preventing sulfide poisoning remains debated.

In the case of Frasassi-dwelling Niphargus, Thiothrix ectosymbionts are located on the walking legs of the animals, which are close to the amphipod gills (Bousfield, 1978). It is thus conceivable that the ectosymbionts might diminish sulfide diffusion into the amphipods' bodies (Dattagupta et al., 2009). The aim of the present study was to determine whether ectosymbionts of $N$. ictus and $N$. frasassianus increase the sulfide tolerances of their hosts. For this purpose, we treated individuals of both Niphargus species with antibiotics to kill their ectosymbionts and subsequently exposed Thiothrixhosting and Thiothrix-lacking Niphargus to cave water whose sulfide content was gradually increased until lethal concentrations were reached.

\section{MATERIALS \& METHODS}

In July 2010, 24 N. ictus and $24 N$. frasassianus individuals were collected from the Frasassi cave lake Lago Verde and from the turbulent cave stream 
Sorgente del Tunnel, respectively (for a map of the Frasassi caves, please refer to Bauermeister et al., 2012). Animals were caught using small fishing nets and forceps, as appropriate, and transferred into polypropylene bottles filled with cave water from the respective sampling site. Additionally, non-sulfidic water was collected from the Frasassi cave pool Il Bugianardo (BG). Niphargus individuals and cave water samples were kept at ambient cave temperature during transfer to the laboratory.

The experiment was conducted at the Osservatorio Geologico di Coldigioco field station in Frontale di Apiro, in a basement room which typically has ambient temperatures of $13-22{ }^{\circ} \mathrm{C}$. Three of the $24 \mathrm{~N}$. ictus individuals died during transfer, so experiments were conducted with only one instead of four $N$. ictus control individuals (details below). An antibiotic solution (12.5 mg/L) was prepared from streptomycin sulfate (Roth, Karlsruhe, Germany) dissolved in filtersterilized BG cave water. Eleven of the $21 \mathrm{~N}$. ictus and 14 of the $24 N$. frasassianus individuals were incubated in the solution for $24 \mathrm{~h}$ in order to kill their Thiothrix ectosymbionts. Streptomycin was chosen as the antibiotic agent due to its high effectiveness against Thiothrix as demonstrated in a previous study (Williams \& Unz, 1985). After the antibiotic treatment, Niphargus individuals were immersed in filter-sterilized BG cave water to wash off any excess streptomycin.

Five beakers, hereafter referred toas B1-B5, were filled with a layer of autoclaved limestone gravel covered by $500 \mathrm{~mL}$ BG cave water (sterilized by filtration through 0.2-micron membranes). Antibiotically treated and non-treated Niphargus were divided into B1-B5 as shown in Fig. 1. Antibiotically treated $N$. ictus $(\mathrm{N}=1)$ and $N$. frasassianus $(\mathrm{N}=4)$ individuals in B5 served as control animals to check whether the streptomycin treatment or other experimental parameters would cause mortality in the absence of sulfide.

A sulfide stock solution (SSS) was prepared from $60 \mathrm{mg}$ of sodium sulfide nonahydrate $\left(\mathrm{Na}_{2} \mathrm{~S} \cdot 9 \mathrm{H}_{2} \mathrm{O}\right.$; SIGMA-ALDRICH, Steinheim, Germany) dissolved in $45 \mathrm{~mL}$ of filter-sterilized BG cave water. Starting one hour after placing the animals in the beakers, a sterile pipette was used to add several milliliters of SSS to B1-B4 at approximately hourly intervals for 13 hours (12 additions in total). The pipette tip was dipped into the water and slowly stirred while releasing the SSS to ensure uniform mixing and prevent rapid oxidation of the sulfide by oxygen (Chen \& Morris, 1972). The same volume of filter-sterilized, non-sulfidic BG cave water was added in a similar manner to B5, serving as control treatment. The number of living Niphargus in the beakers was determined before each addition of SSS. Dissolved sulfide concentrations in the waters were measured with a DR 2800 spectrophotometer using the methylene blue method (HACH LANGE, Düsseldorf, Germany) approximately 15 min after each addition of SSS. Simultaneously, dissolved oxygen, $\mathrm{pH}$, and temperature in the waters were determined using HQ40d multimeter sensors (HACH LANGE). After the third addition of SSS, increasing $\mathrm{pH}$-values of the incubation waters were repeatedly adjusted to $\sim 8$ by addition of a few drops of concentrated hydrochloric acid (Table 1).

After completion of the experiment, six antibiotically treated and five non-treated Niphargus individuals were prepared for examination using scanning electron microscopy (SEM). The specimens were transferred into individual vials filled with $2.5 \%$ glutaraldehyde solution (SIGMA-ALDRICH) made in filter-sterilized BG cave water. They were later sequentially dehydrated in ethanol concentrations from $30 \%$ to $90 \%$, with a final dehydration in hexamethyldisilazane (SIGMAALDRICH) for 5-10 min. The samples were mounted on carbon-coated aluminum sample holders, sputtered with gold-palladium (11 nm thickness), and examined with a LEO 1530 GEMINI field emission SEM (Zeiss, Göttingen, Germany).

Both $N$. ictus and $N$. frasassianus are reported to be endemic to the Frasassi cave ecosystem (Karaman, 1986; Karaman et al., 2010). Due to concerns about threatening their potentially delicate populations, we used a limited number of individuals of each species for our experiment. This precluded replication of the various treatments and statistical analyses of our data.

\section{RESULTS \& DISCUSSION}

SEM revealed that non-treated Niphargus individuals harbored numerous intact Thiothrix filaments, whereas animals treated with streptomycin prior to the experiment featured empty filament sheaths or remnants of Thiothrix holdfasts still attached to their exoskeletons (Fig. 2). These observations confirmed the effective killing of Thiothrix ectosymbionts by the antibiotic treatment. Temperatures in the incubation waters ranged between 20 and $22^{\circ} \mathrm{C}$, which is $7-9{ }^{\circ} \mathrm{C}$ above Frasassi cave water temperatures (Macalady et al., 2006). However, all control animals in B5

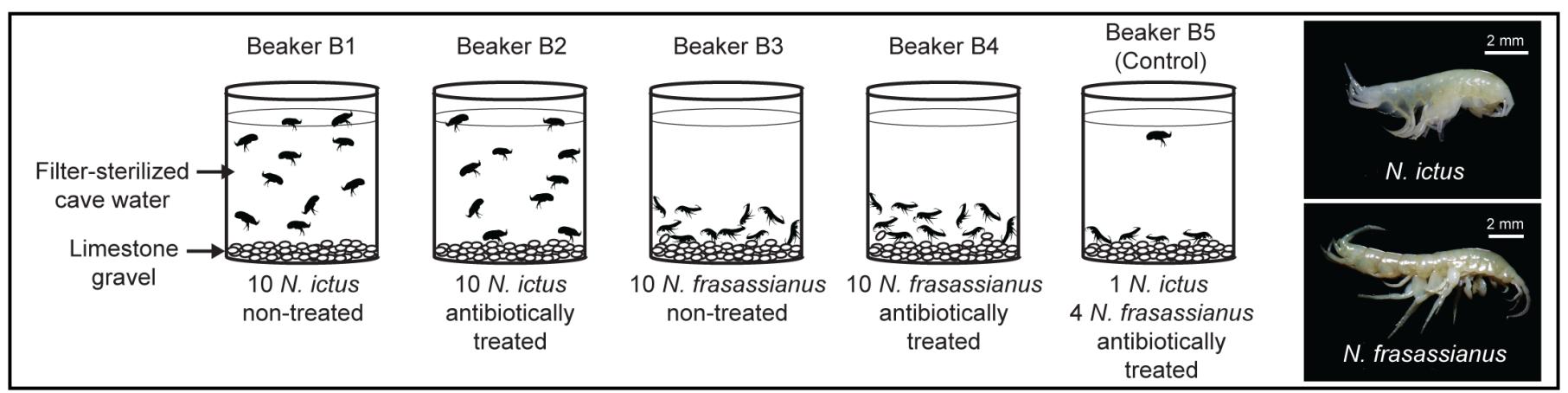

Fig. 1. Experimental set-up of this study. 
Table 1. Overview of the results of the sulfide exposure experiment. Full-length vertical lines indicate time points of sulfide addition.

\begin{tabular}{|c|c|c|c|c|c|c|c|c|c|c|c|c|c|c|}
\hline & Time [h:min] & $0: 00$ & $1: 00$ & 2:15 & 4:00 & $5: 30$ & $6: 45$ & $7: 45$ & $8: 45$ & 9:45 & $10: 45$ & $12: 30$ & 13:15 & $14: 00$ \\
\hline \multirow{3}{*}{$\begin{array}{l}\text { Beaker B1 } \\
N . \text { ictus } \\
\text { non-treated }\end{array}$} & Sulfide [mM] & 0.0 & 0.3 & 1.1 & 0.6 & 0.5 & 1.0 & 2.1 & 3.4 & 2.5 & 3.9 & 7.4 & 7.4 & 14.3 \\
\hline & Oxygen $[\mu \mathrm{M}]$ & 236 & 231 & 201 & 134 & 100 & 80 & 63 & 13 & 85 & 14 & 7 & 32 & 22 \\
\hline & Number of animals alive & 10 & 10 & 10 & 10 & 10 & 10 & 10 & 10 & 10 & 10 & 10 & 10 & 3 \\
\hline \multirow{3}{*}{$\begin{array}{l}\text { Beaker B2 } \\
N . \text { ictus } \\
\text { antibiotically } \\
\text { treated }\end{array}$} & Sulfide [mM] & 0.0 & 0.1 & 0.3 & 0.5 & 0.5 & 1.1 & 1.7 & 4.2 & 3.6 & 5.9 & 9.2 & 12.0 & 16.3 \\
\hline & Oxygen $[\mu \mathrm{M}]$ & 236 & 227 & 214 & 158 & 133 & 108 & 82 & 29 & 45 & 17 & 7 & 14 & 6 \\
\hline & Number of animals alive & 10 & 10 & 10 & 10 & 10 & 10 & 10 & 9 & 8 & 8 & 8 & 7 & 0 \\
\hline \multirow{3}{*}{$\begin{array}{c}\text { Beaker B3 } \\
N . \text { frasassianus } \\
\text { non-treated }\end{array}$} & Sulfide $[\mathrm{mM}]$ & 0.0 & 0.3 & 0.5 & 0.5 & 0.6 & 1.0 & 2.0 & 3.9 & 4.4 & 6.6 & 11.1 & 9.8 & 13.0 \\
\hline & Oxygen $[\mu \mathrm{M}]$ & 236 & 224 & 195 & 143 & 117 & 94 & 58 & 14 & 16 & 20 & 47 & 52 & 13 \\
\hline & Number of animals alive & 10 & 10 & 10 & 10 & 10 & 10 & 10 & 10 & 10 & 10 & 10 & 10 & 0 \\
\hline \multirow{3}{*}{$\begin{array}{c}\text { Beaker B4 } \\
N . \text { frasassianus } \\
\text { antibiotically treated }\end{array}$} & Sulfide $[\mathrm{mM}]$ & 0.0 & 0.2 & 0.4 & 0.5 & 0.5 & 0.9 & 1.5 & 3.2 & 3.7 & 5.5 & 7.4 & 11.5 & 11.4 \\
\hline & Oxygen $[\mu \mathrm{M}]$ & 236 & 234 & 195 & 135 & 112 & 82 & 64 & 32 & 33 & 19 & 10 & 12 & 9 \\
\hline & Number of animals alive & 10 & 10 & 10 & 10 & 10 & 10 & 10 & 10 & 10 & 10 & 10 & 6 & 2 \\
\hline \multirow{3}{*}{$\begin{array}{c}\text { Beaker B5 } \\
\text { control animals } \\
\text { antibiotically } \\
\text { treated }\end{array}$} & Sulfide [mM] & 0.0 & 0.0 & 0.0 & 0.0 & 0.0 & 0.0 & 0.0 & 0.0 & 0.0 & 0.0 & 0.0 & 0.0 & 0.0 \\
\hline & Oxygen $[\mu \mathrm{M}]$ & 236 & 254 & 254 & 235 & 252 & 249 & 247 & 246 & 247 & 242 & 239 & 238 & 237 \\
\hline & $\begin{array}{l}\text { Number of animals alive } \\
(N . \text { ictus }+N \text {. frasassianus) }\end{array}$ & $1+4$ & $1+4$ & $1+4$ & $1+4$ & $1+4$ & $1+4$ & $1+4$ & $1+4$ & $1+4$ & $1+4$ & $1+4$ & $1+4$ & $1+4$ \\
\hline
\end{tabular}

survived the entire experiment (Table 1), implying that temperature did not play a defining role in mortality.

All antibiotically treated $N$. ictus and $N$. frasassianus individuals survived sulfide concentrations of $1.7 \mathrm{mM}$ and $1.5 \mathrm{mM}$, respectively (Table 1). These concentrations are more than three times as high as those measured in Frasassi cave waters $(0.1$ to $0.5 \mathrm{mM}$ sulfide; Galdenzi et al., 2008). Thus, the Thiothrix ectosymbionts of $N$. ictus and $N$. frasassianus are probably not essential for preventing sulfide poisoning of their hosts in the cave waters. At sulfide levels between 3 and $7 \mathrm{mM}$, we observed that two antibiotically treated $N$. ictus died, whereas all untreated individuals survived (Table 1). Although we cannot rule out that the ectosymbionts provided a survival advantage at these high sulfide levels, it is perhaps more likely that the antibiotic treatment weakened the Niphargus, making them less resistant to high sulfide and/or low oxygen concentrations.

Amphipods generally have low sulfide tolerances (Theede et al., 1969; Oseid \& Smith, 1974; Sandberg-
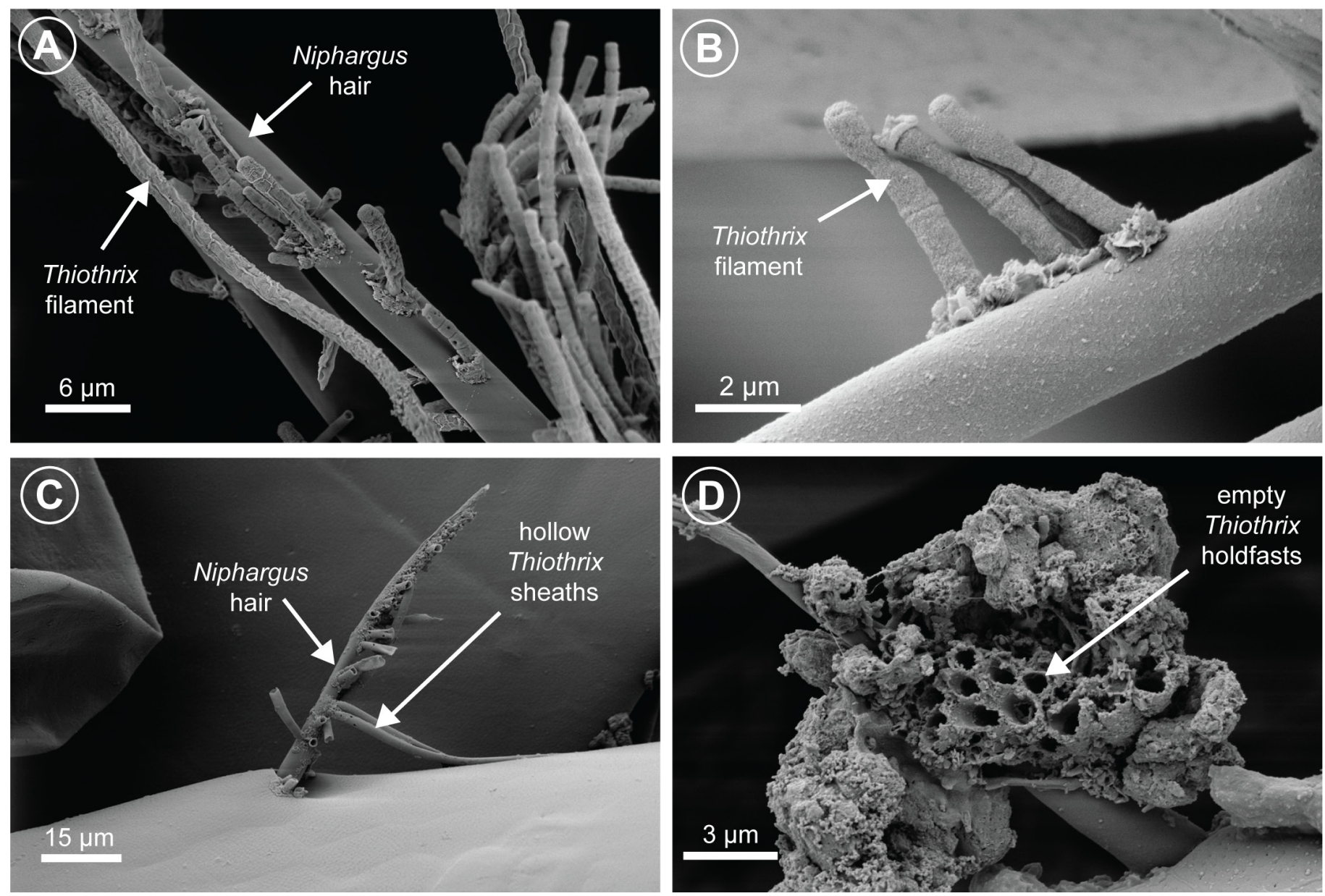

Fig. 2. Scanning electron micrographs of intact filaments and remnants of Thiothrix ectosymbionts on Niphargus. Panels A and B: Intact ectosymbiotic Thiothrix filaments on Niphargus (images are of Niphargus individuals not subjected to the sulfide experiment). Panels C and D: Empty Thiothrix sheaths and holdfasts on Niphargus individuals treated with streptomycin solution. 
Kilpi et al., 1999). Knezovich et al. (1996) found that all 20 individuals of the infaunal amphipod Rhepoxynius abronius used for their experiment had died after $48 \mathrm{~h}$ exposure to $78 \mu \mathrm{M}$ sulfide, and 14 out of 20 individuals of the infaunal amphipod Eohaustorius estuarius had died after $48 \mathrm{~h}$ exposure to 116 $\mu \mathrm{M}$ sulfide. In our experiment, all 20 non-treated $N$. ictus and $N$. frasassianus individuals survived sulfide concentrations as high as $7 \mathrm{mM}$ (Table 1). To the best of our knowledge, this is to date the highest experimentally determined sulfide concentration tolerated by a crustacean (Vaquer-Sunyer \& Duarte, 2010). Frasassi-dwelling Niphargus could presumably employ symbiont-independent sulfide detoxification processes. Crustaceans are commonly not able to exclude sulfide from their bodies, but they can oxidize it to non-toxic thiosulfate or sulfite. Detoxification is either mediated enzymatically by sulfide oxidase (Vetter et al., 1987) or proceeds via oxygen-independent sulfide binding to metallic ions (Vismann, 1991). Additionally, mitochondrial sulfide oxidation has been suggested to occur in the muscle tissue of certain crustaceans (Vismann, 1991; Johns et al., 1997).

\section{CONCLUSION}

$N$. ictus and $N$. frasassianus amphipods living in sulfide-rich waters of the Frasassi cave system appear to have exceptionally high sulfide tolerances compared to other crustaceans studied to date. However, their sulfide-oxidizing Thiothrix ectosymbionts are unlikely to play a critical role in sulfide detoxification. It remains to be examined whether these bacteria provide the Niphargus with other benefits.

\section{ACKNOWLEDGEMENTS}

The authors thank Alessandro Montanari for providing lab facilities and logistical support at the Osservatorio Geologico di Coldigioco. Sincere thanks are also given to Anne Wilkening for assistance during the sulfide experiment, and to Dorothea Hause-Reitner and Wolfgang Dröse for assistance with scanning electron microscopy. The study was funded by the German Initiative of Excellence. This is publication number 119 from the Courant Research Center Geobiology of the University of Göttingen.

\section{REFERENCES}

Anderson A.E., Childress J.J. \& Favuzzi J.A., 1987 - Net uptake of $\mathrm{CO}_{2}$ driven by sulphide and thiosulphate oxidation in the bacterial symbiont-containing clam Solemya reidi. Journal of Experimental Biology, 133: 1-31.

http://jeb.biologists.org/content/133/1/1

Bauermeister J., Ramette A. \& Dattagupta S., 2012 Repeatedly evolved host-specific ectosymbioses between sulfur-oxidizing bacteria and amphipods living in a cave ecosystem. PLoS ONE, 7: e50254.

http://dx.doi.org/10.1371/journal.pone.0050254

Bousfield E.L., 1978 - A revised classification and phylogeny of amphipod crustaceans. Transactions of the Royal Society of Canada, 16: 343-390.
Cavanaugh C.M., McKiness Z.P., Newton I.L.G. \& Stewart F.J., 2006 - Marine chemosynthetic symbioses. In: Dworkin M., Falkow S., Rosenberg E., Schleifer K.H. \& Stackebrandt E. (Eds.) - The Prokaryotes, 3rd Edition. New York: Springer: 475-507.

http://dx.doi.org/10.1007/0-387-30741-9 18

Chen K.Y. \& Morris J.C., 1972 - Kinetics of oxidation of aqueous sulfide by $\mathrm{O}_{2}$. Environmental Science \& Technology, 6: 529-537. http://dx.doi.org/10.1021/es60065a008

Dattagupta S., Schaperdoth I., Montanari A., Mariani S., Kita N., Valley J.W. \& Macalady J.L., 2009 - A novel symbiosis between chemoautotrophic bacteria and a freshwater cave amphipod. The ISME Journal, 3: 935-943. http://dx.doi.org/10.1038/ismej.2009.34

Dubilier N., Giere O. \& Grieshaber M.K., 1995 Morphological and ecophysiological adaptations of the marine oligochaete Tubificoides benedii to sulfidic sediments. American Zoologist, 35: 163-173. http://dx.doi.org/10.1093/icb/35.2.163

Dubilier, Bergin C. \& Lott C., 2008 - Symbiotic diversity in marine animals: the art of harnessing chemosynthesis. Nature Reviews Microbiology, 6: 725-740. http://dx.doi.org/10.1038/nrmicro1992

Flot J.-F., Wörheide G. \& Dattagupta S., 2010 Unsuspected diversity of Niphargus amphipods in the chemoautotrophic cave ecosystem of Frasassi, central Italy. BMC Evolutionary Biology, 10: 171.

http://dx.doi.org/10.1186/1471-2148-10-171

Galdenzi S., 1990 - Un modello genetico per la Grotta Grande del Vento. In: Galdenzi S. \& Menichetti M. (Eds.) Il carsismo della Gola di Frasassi. Memorie dell'Instituto Italiano di Speleologia, Serie II, Volume 4: 123-142.

Galdenzi S., Cocchioni M., Morichetti L., Amici V. \& Scuri S., 2008 - Sulfidic ground-water chemistry in the Frasassi Caves, Italy. Journal of Cave and Karst Studies, 70: 94-107.

http://www.caves.org/pub/journal/PDF/v70/cave70-02-94.pdf

Hentschel U., Berger E.C., Bright M., Felbeck H. \& Ott J.A., 1999 - Metabolism of nitrogen and sulfur in ectosymbiotic bacteria of marine nematodes (Nematoda, Stilbonematinae). Marine Ecology Progress Series, 183: 149-158. http://dx.doi.org/10.3354/meps 183149

Johns A.R., Taylor A.C., Atkinson R.J.A. \& Grieshaber M.K., 1997 - Sulphide metabolism in thalassinidean crustacea. Journal of the Marine Biological Association of the United Kingdom, 77: 127-144.

http://dx.doi.org/10.1017/S0025315400033828

Karaman G., 1986 - New data on the genus Niphargus Schiodte (Fam. Niphargidae) in Italy and adjacent regions (Contribution to the Knowledge of the Amphipoda 138). Bollettino del Museo Civico di Storia Naturale, Verona, 12: 209-228.

Karaman G., Borowsky B. \& Dattagupta S., 2010 - Two new species of the genus Niphargus Schiödte, 1849 (Amphipoda, fam. Niphargidae) from the Frasassi cave system in central Italy. Zootaxa, 2439: 35-52. http://www.mapress.com/zootaxa/2010/f/zt02439p052.pdf

Knezovich J.P., Steichen D.J., Jelinski J.A. \& Anderson S.L., 1996 - Sulfide tolerance of four marine species used to evaluate sediment and pore-water toxicity. Bulletin of Environmental Contamination and Toxicology, 57: 450-457.

http://dx.doi.org/10.1007/s001289900211

Macalady J.L., Lyon E.H., Koffman B., Albertson L.K., Meyer K., Galdenzi S. \& Mariani S., 2006 - Dominant microbial populations in limestone-corroding stream biofilms, Frasassi cave system, Italy. Applied and Environmental Microbiology, 72: 5596-5609. http://dx.doi.org/10.1128/AEM.00715-06 
Nicholls P., 1975 - The effect of sulphide on cytochrome $a a_{3}$ isosteric and allosteric shifts of the reduced a-peak. Biochimica et Biophysica Acta, 396: 24-35. http://dx.doi.org/10.1016/0005-2728(75)90186-3

Oseid D.M. \& Smith L.L., 1974 - Factors influencing acute toxicity estimates of hydrogen sulfide to freshwater invertebrates. Water Research, 8: 739-746.

http://dx.doi.org/10.1016/0043-1354(74)90018-9

Ruehland C. \& Dubilier N., 2010 - Gamma- and epsilonproteobacterial ectosymbionts of a shallowwater marine worm are related to deep-sea hydrothermal vent ectosymbionts. Environmental Microbiology, 12: 2312-2326. http:/ / dx.doi.org/10.1111/j.1462-2920.2010.02256.x

Sandberg-Kilpi E., Vismann B. \& Hagerman L., 1999 Tolerance of the Baltic amphipod Monoporeia affinis to hypoxia, anoxia and hydrogen sulfide. Ophelia, 50: 61-68. http://dx.doi.org/10.1080/00785326.1999.10409389

Sarbu S.M., Galdenzi S., Menichetti M. \& Gentile G., 2000 - Geology and biology of the Frasassi caves in central Italy: an ecological multi-disciplinary study of a hypogenic underground karst system. In: Wilkens H., Culver D.C. \& Humphreys W.F. (Eds.) - Subterranean ecosystems. Ecosystems of the world. Amsterdam: Elsevier Science: 359-378.

Theede H., Ponat A., Hiroki K. \& Schlieper C., 1969 Studies on the resistance of marine bottom invertebrates to oxygen-deficiency and hydrogen sulphide. Marine Biology, 2: 325-337.

http://dx.doi.org/10.1007/BF00355712
Tokuda G., Yamada A., Nakano K., Arita N.O. \& Yamasaki H., 2008 - Colonization of Sulfurovum $s p$. on the gill surfaces of Alvinocaris longirostris, a deep-sea hydrothermal vent shrimp. Marine Ecology, 29: 106-114. http://dx.doi.org/10.1111/j.1439-0485.2007.00211.x

Vaquer-Sunyer R. \& Duarte C.M., 2010 - Sulfide exposure accelerates hypoxia-driven mortality. Limnology and Oceanography, 55: 1075-1082.

http://dx.doi.org/10.4319/1o.2010.55.3.1075

Vetter R.D., Wells M.E., Kurtsman A.L. \& Somero G.N., 1987 - Sulfide detoxification by the hydrothermal vent crab Bythograea thermydron and other decapod crustaceans. Physiological Zoology, 60: 121-137.

Vismann B., 1991 - Physiology of sulfide detoxification in the isopod Saduria (Mesidotea) entomon. Marine Ecology Progress Series, 76: 283-293. http://dx.doi.org/10.3354/meps076283

Williams T.M. \& Unz R.F., 1985 - Filamentous sulfur bacteria of activated sludge: characterization of Thiothrix, Beggiatoa, and Eikelboom Type 021N strains. Applied and Environmental Microbiology, 49: 887-898. http://aem.asm.org/content/49/4/887.long

Wilmot D.B. \& Vetter R.D., 1990 - The bacterial symbiont from the hydrothermal vent tubeworm Riftia pachyptila is a sulfide specialist. Marine Biology, 106: 273-283. http://dx.doi.org/10.1007/BF01314811 